\title{
Histopathological study of porcine gastric mucosa with and without a spiral bacterium ("Gastrospirillum suis")
}

\author{
E. N. MENDES, DULCIENE M. M. QUEIROZ, G. A. ROCHA, ANA M. M. F. NOGUEIRA*, \\ A. C. T. CARVALHO, A. P. LAGE and A. J. A. BARBOSA*
}

Laboratory of Research in Bacteriology and "Department of Pathology, Faculdade de Medicina, Universidade Federal de Minas Gerais, Av. Alfredo Balena, 190/464-CEP 30130, Belo Horizonte, Minas Gerais, Brazil

\begin{abstract}
Summary. Tightly spiralled bacteria ("Gastrospirillum suis") were seen in the pyloric mucosa of the stomach of $13(10.8 \%)$ of 120 pigs that appeared clinically healthy at slaughter and in the fundic mucosa of three $(5.0 \%)$ out of 60 pigs. The spiral organism could not be cultured from any pig. Chronic gastritis was observed in the pyloric mucosa of $53(44 \cdot 2 \%)$ of 120 pigs and in the fundic mucosa of $7(11.7 \%)$ of 60 pigs. The 13 pigs with spiral bacteria in the pyloric region comprised one animal $(7.7 \%)$ with normal pyloric mucosa, two $(15 \cdot 4 \%)$ with "borderline gastritis", and $10(76.9 \%)$ with chronic gastritis-in one instance accompanied by signs of activity (numerous polymorphonuclear cells). The three pigs with spiral bacteria in the fundic mucosa comprised two animals with a normal fundic region and one with "borderline gastritis". The presence of the spiral bacterium was significantly associated with pyloric gastritis $(p=0.013)$ and with numbers of lymphoid follicles $(p=0.014)$.
\end{abstract}

\section{Introduction}

Interest in gastric microbiology and histopathology has increased since 1983, when Warren ${ }^{1}$ and Marshall ${ }^{2}$ described a spiral bacterium, now named Helicobacter pylori, in the stomachs of patients with gastritis and peptic ulcer. This bacterium is now recognised as the most important causal agent of antral gastritis in man. ${ }^{3}$

Although naturally occurring spiral bacteria have been seen consistently in the stomach of some other mammals, ${ }^{4-9}$ they have not been associated with pathological changes, ${ }^{10,11}$ except in ferrets. ${ }^{12}$ In animals, spiral bacteria tend to infect the gastric body and are commonly seen deep in the gastric glands and within parietal cells. . $^{4,9,11}$

Recently, we described a tightly spiralled bacterium, provisionally named "Gastrospirillum suis", colonising the pyloric and fundic mucosa of the pig stomach. ${ }^{13,14}$

In the present report, we describe a histological study of the pyloric and fundic mucosa of pig stomachs colonised by "G. suis" or free from the organism.

\section{Materials and methods}

\section{Animals}

Two series of male and female pork-weight pigs (mean weight $110 \mathrm{~kg}$ ), slaughtered at about 6 months

Received 22 Oct. 1990; accepted 26 Feb. 1991.

Correspondence should be sent to Dr D. M. M. Queiroz. of age, were studied. In the first series, fragments of gastric tissue from the pyloric region of 60 pigs were collected. In the second, fragments from both the pyloric and fundic mucosa were obtained from a further 60 pigs.

The stomachs were opened along the greater curvature and thoroughly washed in tap water. Macroscopic lesions, when present, were noted; chronic gastritis was suspected when surface oedema and redness were present in the mucosa, with or without erosions and areas showing haemorrhage.

Tissue samples of the pyloric mucosa were taken from the lesser curvature, $4 \mathrm{~cm}$ from the torus piloricus. Samples of the fundic mucosa were obtained from the greater curvature of the gastric body.

\section{Histological examination}

Fragments of the pyloric and fundic mucosa were fixed in Bouin's fluid for 18-24 h, dehydrated in an alcohol-xylene series, and embedded in paraffin wax. From each block, sections $4 \mu \mathrm{m}$ thick were prepared and stained with haematoxylin and eosin (H\&E) for histological examination, or with carbol fuchsin ${ }^{15}$ for the detection of spiral bacteria.

Gastric mucosa was regarded as normal when there was a complete lack of mononuclear and polymorphonuclear cells in the lamina propria throughout its entire thickness and no changes were observed in the glands and superficial epithelium. Chronic gastritis was indicated by the presence of mononuclear cells with a few polymorphonuclear cells. The presence of 
many polymorphonuclear cells was taken to indicate activity.

The term "borderline gastritis" was used to describe cases in which there was infiltration of discrete mononuclear cells in the lamina propria without other changes. This infiltration was diffusely or focally distributed in both the basal and superficial regions of the mucosa. "Borderline gastritis" was included in the category of "normal or near normal mucosa" as described previously, ${ }^{16}$ the infiltration of mononuclear cells being too slight to be considered to indicate chronic gastritis. The presence of lymphoid follicles with prominent germinal centres was recorded.

\section{Microbiological examination}

In the first series, fragments from the pyloric mucosa of each stomach were kept in thioglycollate broth at $4^{\circ} \mathrm{C}$ for no longer than $2 \mathrm{~h}$ before being cultured in anaerobic, aerobic and micro-aerophilic conditions. ${ }^{17}$ Plates containing Belo Horizonte medium, ${ }^{17}$ Skirrow's medium, ${ }^{18}$ Butzler's medium, ${ }^{18}$ and Brucella agar supplemented with sheep blood $10 \%$ were used.

In the second series, specimens of pyloric and fundic mucosa were cultured similarly but on three selective media consisting of Brucella agar plus sheep blood $10 \%$ and one of the following three supplements: (i) amphotericin B $2 \mathrm{mg} / \mathrm{L}$; (ii) amphotericin B $2 \mathrm{mg} / \mathrm{L}$, vancomycin $6 \mathrm{mg} / \mathrm{L}$ and trimethoprim $5 \mathrm{mg} / \mathrm{L}$; or (iii) amphotericin B $2 \mathrm{mg} / \mathrm{L}$, vancomycin $6 \mathrm{mg} / \mathrm{L}$, nalidixic acid $20 \mathrm{mg} / \mathrm{L}$ and starch $1 \mathrm{~g} / \mathrm{L}$. Separate sets of plates were incubated at $25^{\circ} \mathrm{C}, 37^{\circ} \mathrm{C}$ and $42^{\circ} \mathrm{C}$ and examined daily for up to 7 days.

Statistical analysis was done by the Fisher and Mantel-Haenszel $\chi^{2}$ tests. The results were considered to be significant when $p<0.05$.

\section{Results}

The results of the two series are described together.

In six pigs with macroscopic changes suggestive of pyloric chronic gastritis, histological features of gastritis were found. However, some pigs had histological evidence of gastritis of the pylorus in the absence of macroscopic signs.

Tightly spiralled bacteria were seen on the pyloric mucosa of $13(10.8 \%)$ of 120 pigs and on the fundic mucosa of $3(5.0 \%)$ of 60 animals. All pigs in which spiral bacteria were observed in the fundic mucosa also had these organisms in the pyloric region. The bacteria were more numerous in the pyloric than fundic mucosa and were found in the mucus, in the lumen of the pits, and in the mucosal surface within or beneath the mucus (fig. 1). Micro-organisms were not seen in lymphoid follicles, macrophages or the lamina propria. Neither the tightly spiralled bacteria nor $\boldsymbol{H}$. pylori could be cultured from any pig. Animals were considered bacterium-positive when tightly spiralled micro-organisms were detected in gastric

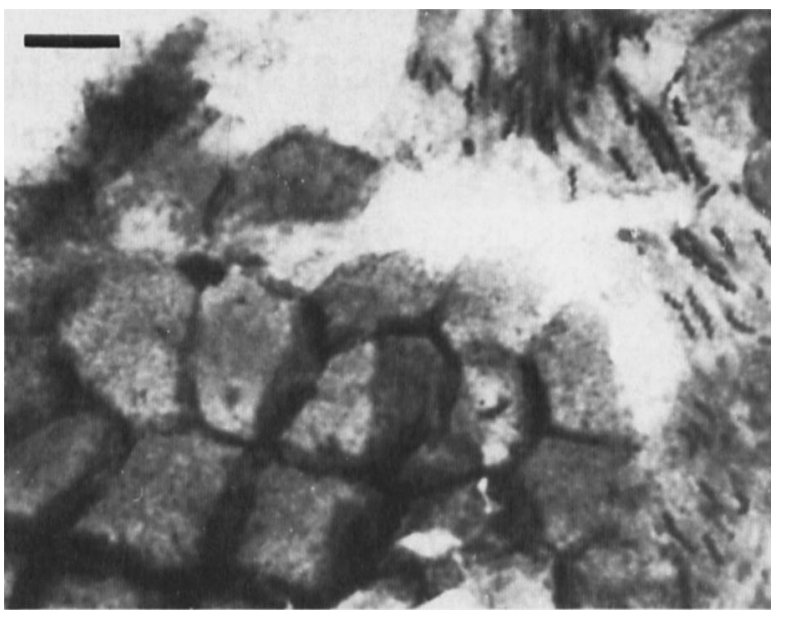

Fig. 1. Tightly spiralled bacteria in the pyloric mucosa of a pig (carbol-fuchsin staining). Bar, $2.5 \mu \mathrm{m}$.

mucosa, irrespective of whether they were present only in the pyloric region or in both the pyloric and fundic regions.

Histological findings are shown in the table. Chronic gastritis (excluding "borderline gastritis") was observed in the pyloric mucosa of $53(44.2 \%)$ of 120 pigs and in the fundic mucosa of $7(11.7 \%)$ of 60 . The 13 pigs with spiral bacteria in the pyloric region comprised one animal $(7.7 \%)$ with normal pyloric mucosa (fig. 2), two (15.4\%) with "borderline gastritis", and $10(76.9 \%)$ with chronic gastritis (fig. 3 ), one of them with signs of activity (numerous polymorphonuclear cells). Of the three pigs with spiral bacteria in the fundic region, two had normal mucosa and one had "borderline gastritis". Fundic mucosa was normal in the other four bacterium-positive pigs, in which tightly spiralled bacteria were observed only in the pyloric mucosa. Such bacteria were not observed in the seven pigs that had chronic gastritis in the fundic mucosa.

Table. Histopathological findings in the pyloric and fundic mucosa of the stomach of pigs

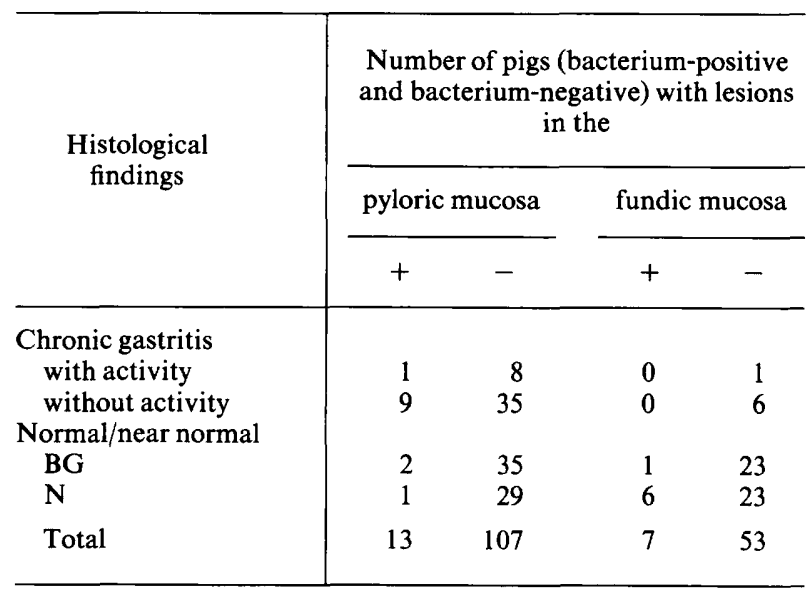

"Bacterium-positive" means spiralled organisms observed in the pyloric or pyloric and fundic gastric mucosa; BG, "borderline gastritis"; N, normal. 


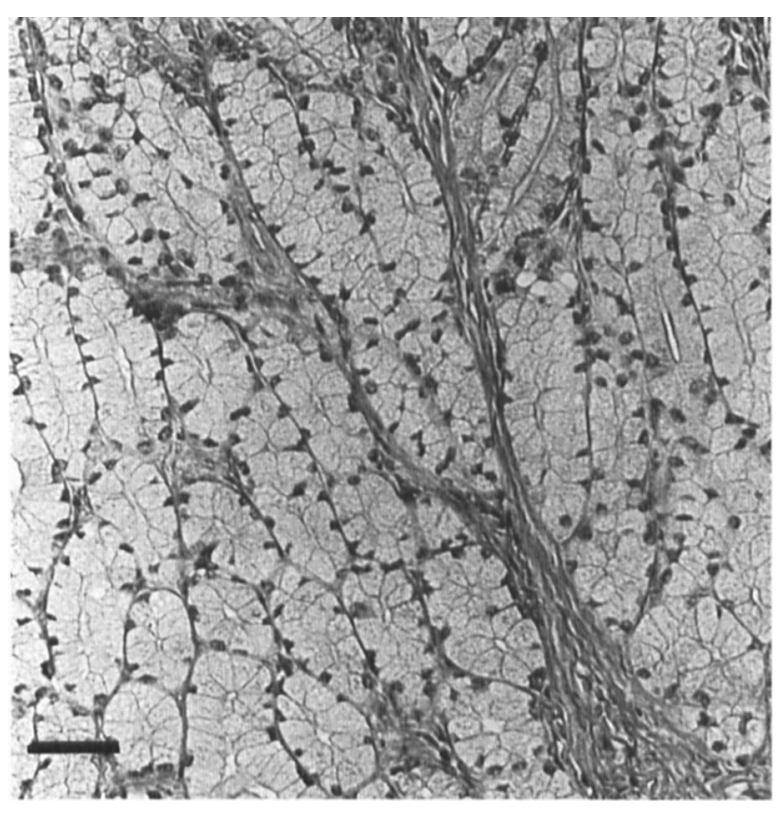

Fig. 2. Normal pyloric mucosa of the pig (H\&E). Bar, $32 \cdot 25 \mu \mathrm{m}$.

Chronic pyloric gastritis (excluding "borderline gastritis") was significantly more common in bacterium-positive than in -negative pigs $(p=0.013)$. In contrast, there was no such association in the fundic mucosa $(p=0 \cdot 399)$. Chronic gastritis in both the pyloric and fundic mucosa was observed in only five $(8.3 \%)$ of 60 pigs, all of which were free from the bacterium.

Large lymphoid follicles with prominent germinal centres (fig. 4) were found in the lamina propria and submucosa of the pyloric region of $29(24 \cdot 1 \%)$ of 120 pigs. They were associated with normal mucosa in seven pigs, with "borderline gastritis" in a further

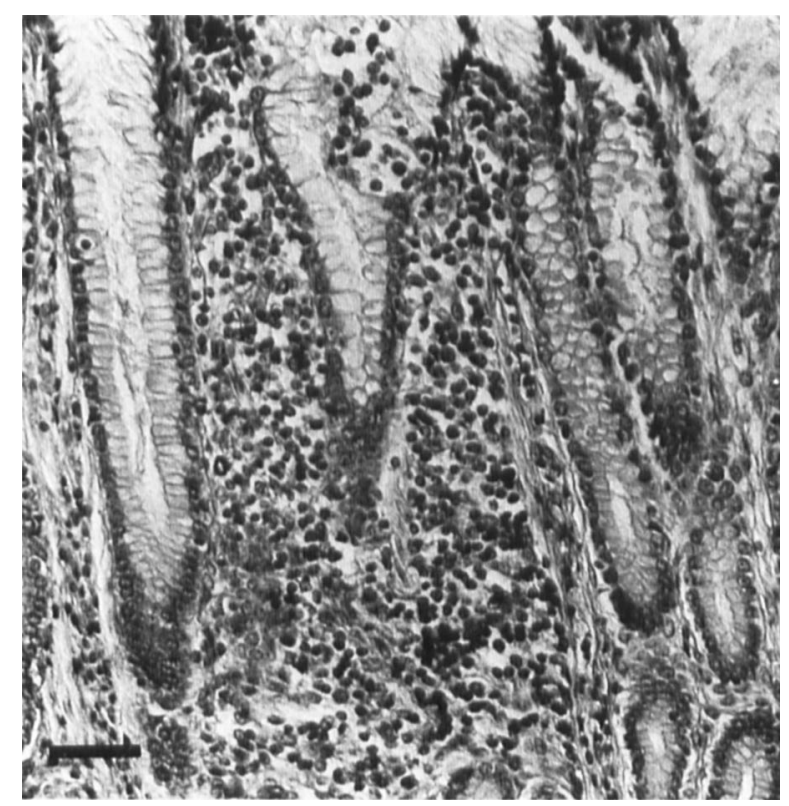

Fig. 3. Pyloric mucosa of a pig with chronic gastritis characterised by large numbers of mononuclear cells and a few granulocytes in the upper third of the lamina propria (H\&E). Bar, $12.5 \mu \mathrm{m}$.

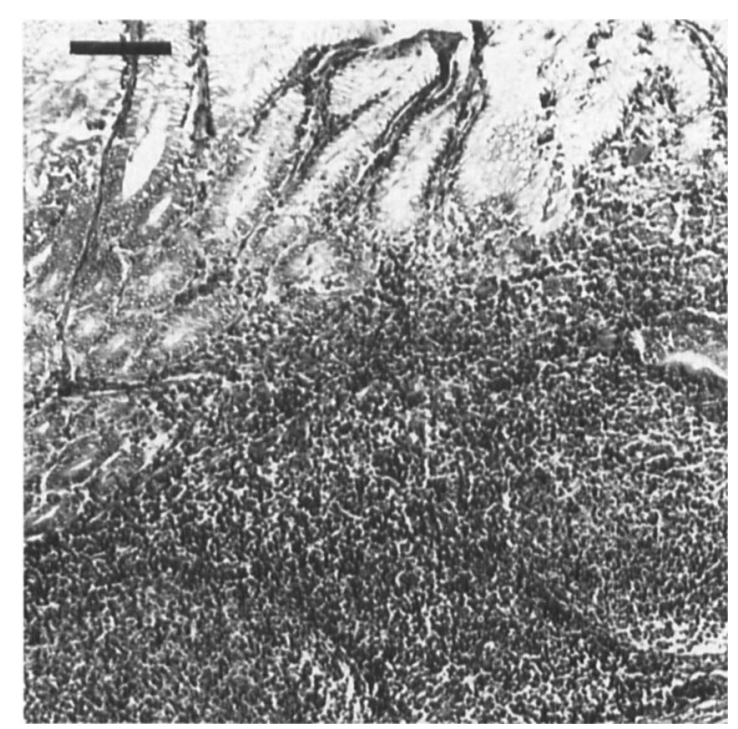

Fig. 4. Lymphoid follicle in pyloric mucosa of a pig (H\&E). Bar, $32 \cdot 25 \mu \mathrm{m}$.

seven and with chronic gastritis in the remaining 15 animals. There was a significant difference $(p=0.014)$ between the occurrence of lymphoid follicles in bacterium-positive pigs ( 7 of $13 ; 53.8 \%$ ) and -negative ones $(22$ of $107 ; 20.6 \%)$.

\section{Discussion}

Naturally occurring gastritis in laboratory and domestic animals has been reported infrequently, and gastric histology of pigs is seldom mentioned in reviews of stomach diseases in animals. Chronic gastritis of the cardiac region and of the pars oesophagea is thought to occur sporadically in pigs, but no cause has been found. ${ }^{19}$ Spiral-shaped organisms may be demonstrated in the stomachs of many animal species, ${ }^{4-9}$ but in only one instance-in ferrets colonised by $H$. mustelae-have they been associated with gastritis. ${ }^{12}$

The results reported here showed a significant association between the presence of spiral bacteria and chronic pyloric gastritis in pigs. The histological findings were similar to those reported in $\operatorname{man}^{16,20}$ and in gnotobiotic piglets ${ }^{21,22}$ colonised by $\boldsymbol{H}$. pylori. There was also a significant association between the presence of " $G$. suis" and lymphoid follicles. The latter have previously been related, in man, to an immune response to gastric colonisation by $H$. pylori ${ }^{23}$ In some "G. suis"-positive pigs, the fundic mucosa was normal despite the presence of pyloric gastritis. This is also common in $H$. pylori infection in man. ${ }^{16,20}$

Pyloric gastritis was also seen in bacterium-negative pigs. Probably there are many causes of chronic gastritis in swine, e.g., dietary habits ${ }^{24}$ and parasites such as Hyostrongylus rubidus, Ascarops spp., Physocephalus spp. and Simondsia spp. ${ }^{19}$ Candidiasis of the 
pars oesophagea may also occur, often in association with pre-ulcerative epithelial hyperplasia and parakeratosis. ${ }^{19}$ It is possible that the methods used were not sensitive enough to detect all " $G$. suis"-positive pigs. Recently Dick et al. ${ }^{25}$ used mouse inoculation as a means of maintaining non-cultivable gastric spiral bacteria. Employing this method in another series of pigs, we detected "G. suis" in some animals that were negative for this micro-organism by the urease test and carbol fuchsin staining (unpublished results).

It remains to be established whether " $G$. suis" is a pathogen, or whether it colonises previously damaged areas of the gastric mucosa. Further information, for

\section{References}

1. Warren JR. Unidentified curved bacilli on gastric epithelium in active chronic gastritis. Lancet 1983; 1: 1273 .

2. Marshall B. Unidentified curved bacilli on gastric epithelium in active chronic gastritis. Lancet 1983; 1: 1273-1275.

3. Graham DY. Campylobacter pylori and peptic ulcer disease. Gastroenterology 1989; 96: 615-625.

4. Doenges JL. Spirochetes in the gastric glands of macacus rhesus and of man without related disease. Arch Pathol 1939; 27 469-477.

5. Kasai K, Kobayashi R. The stomach spirochete occurring in mammals. J Parasitol 1919; 6: 1-11.

6. Krieg NR. Biology of chemoheterotrophic spirilla. Bacteriol Rev 1976; 40: 55-115.

7. Lee A, Hazell SL, O'Rourke J, Kouprach S. Isolation of a spiral-shaped bacterium from the cat stomach. Infect Immun $1988 ; 56: 2843-2850$

8. Sato T, Takeuchi A. Infection by spirilla in the stomach of resus monkey. Vet Pathol 1982; 19 Suppl 7: 17-25.

9. Weber AF, Hasa O, Sautter JH. Some observations concerning the presence of spirilla in the fundic glands of dogs and cats. Am J Vet Res 1958; 19: 677-680.

10. Lockard VG, Boler RK. Ultrastructure of a spiraled microorganism in the gastric mucosa of dogs. Am J Vet Res $1970 ; 31: 1453-1462$.

11. Marshall BJ. Experimental models in vivo for Campylobacter pylori. Gastroenterol Clin Biol 1989; 13: 50B-52B.

12. Fox JG, Cabot EB, Taylor NS, Laraway R. Gastric colonization by Campylobacter pylori subsp. mustelae in ferrets. Infect Immun 1988; 56: 2994-2996.

13. Queiroz DMM, Rocha GA, Mendes EN, Lage AP, Carvalho ACT, Barbosa AJA. A spiral microorganism in the stomach of pigs. Vet Microbiol 1990; 24: 199-204.

14. Mendes EN, Queiroz DMM, Rocha GA, Moura SB, Leite VHR, Fonseca MEF. Ultrastructure of a spiral microorganism from pig gastric mucosa ("Gastrospirillum suis") J Med Microbiol 1990; 33: 61-66. example on the effect of eradicating the organism by antibiotic treatment, is necessary for a better understanding of the role of " $G$. suis" in the pathogenesis of chronic gastritis in the pig.

It is not known whether histologically detectable gastritis in pigs depresses growth rate or the efficient utilisation of food. If it does, "G. suis", which was found in almost $20 \%$ of all cases of chronic gastritis in the pigs studied, deserves further attention.

This work was supported by grants from FAPEMIG and FINEP (Brazil). We thank Mr P. P. Silva for proficient technical assistance and Frigorifico São João Ltd for providing the pigs stomachs.

15. Rocha GA, Queiroz DMM, Mendes E, Lage AP, Barbosa AJA Simple carbolfuchsin staining for showing $C$, pylori and other spiral bacteria in gastric mucosa. J Clin Pathol 1989; 42: 1004-1005.

16. Queiroz DMM, Barbosa AJA, Mendes EN et al. Distribution of Campylobacter pylori and gastritis in the stomach of patients with and without duodenal ulcer. Am J Gastroenterol 1988; 83: 1368-1370.

17. Queiroz DMM, Mendes EN, Rocha GA. Indicator medium for isolation of Campylobacter pylori. J Clin Microbiol 1987 25: 2378-2379.

18. Butzler JP, Skirrow MB. Campylobacter enteritis. Clin Gastroenterol $1979 ; 8: 737-765$.

19. Jubb KVF, Kennedy PC, Palmer N. The lower alimentary system. In: Pathology of domestic animals, 3rd edn, vol 2. London, Academic Press. 1985: 42-49.

20. Hazell SL, Hennessy WB, Borody TJ et al. Campylobacter pylor gastritis II : Distribution of bacteria and associated inflammation in the gastroduodenal environment. Am J Gastroenterol 1987; 82: 297-301.

21. Krakowka S, Morgan DR, Kraft WG, Leunk RD. Establishment of gastric Campylobacter pylori infection in the neonatal gnotobiotic piglet. Infect Immun 1987; 55: 27892796.

22. Lambert JR, Borromeo M, Pinkard KJ, Turner H, Chapman CB, Smith ML. Colonization of gnotobiotic piglets with Campylobacter pyloridis - an animal model? I Infect Dis 1987; 155: 1344 .

23. Stolte M, Eidt $\mathbf{S}$. Lymphoid follicles in antral mucosa : immune response to Campylobacter pylori? J Clin Pathol 1989; 42 . 1269-1271

24. Guizzardi F, Cabassi E, Freddi M. Gastrite da alimentazione con insilato di mais nel maiale. Suinicoltura $1981 ; 22: 47$ 52.

25. Dick E, Lee A, Watson G, O'Rourke J. Use of the mouse for the isolation and investigation of stomach-associated, spiral-helical shaped bacteria from man and other animals. J Med Microbiol 1989; 29: 55-62. 